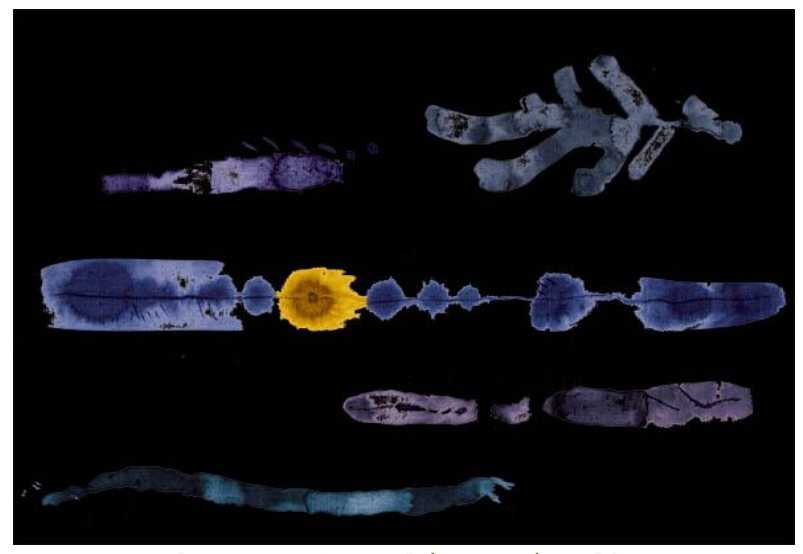

Ilustração Alice Bicalho

\title{
Este rosto sem nome
}

\section{João Rocha}

Mestrando em Teoria da Literatura na FALE/UFMG.

Eu podia ver. Podia vê-lo. Era um homem, mas se parecia mais com um animal. Sim. Era um animal, mas era, ainda, um homem. Era magro e muito alto. O homem, que era também um animal, era o homem mais magro e mais alto que já vi.

"É um homem ou um animal que desponta na paisagem?", pensei.

Era um homem animal. Um animal homem selvagem. Animal escrito. Ele possuía uma expressão confusa. Seus olhos estavam estatelados e pareciam ver tudo. Eram olhos de cão. Tinham aquele abismo que os cães carregam no olhar.

"É um animal humano", pensei.

Aproximo-me dele.

A palidez de seu rosto escorria por todo o corpo. Ele estava nu. Pelo menos só poderia vê-lo assim, nu. Seu sexo era branco e pálido. Não tinha pêlos. Como era branco aquele homem. Branco como uma folha de papel que aguarda o texto futuro. Isso. Esse animal humano era um corpo aberto como uma folha de papel. Seu sexo era da mesma natureza do sexo de uma folha que ainda não está escrita.

Aproximo-me.

De mais perto, posso ver sua boca que mais parecia um átrio, um buraco de onde se ouvia sons bizarros. Ele me diz: 
"Sou oco por dentro, podes ver?"

De fato, era possível ver o que me dizia.

"Meus pensamentos são sensações", disse -me, enquanto via escorre por sobre seu corpo palavras que se estendiam por toda a paisagem. "Assim é como olho o mundo. Estou em toda parte e em parte alguma".

"Paisagem escrita", pensei.

"Paisagem por escrito", ele disse.

De mais perto, pude ver que trazia as mãos em forma de concha e dentro delas trazia algo.

"Meu coração", ele me disse.

"Por que trazes teu coração nas mãos?", perguntei.

"Sou um louco", disse ele.

Ele estendeu então as mãos em minha direção e disse:

"Pega, é teu. Faça dele o que quiseres".

Segurei o coração daquele homem-animal-escrito em minhas mãos sem sentir medo. Assustei-me, pois o que transcorria ante os meus olhos era violento demais e não me causava medo. Ele então toucou meu rosto e disse-me:

"Não te assustes." Tocou o sexo e retomou: "não é lindo?".

De fato, o era. Seu sexo era uma abertura donde se podia ver o que estava por vir. O mundo emoldurado em branco, era o que se via no sexo daquele homem.

"Queres tocá-lo?", ele me perguntou.

"Não posso", respondi.

"Tenta."

"Tenho medo de perder-me".

Foi quando vi que seu sexo animal espalhava-se pela paisagem. Ele tocava tudo o que encontrava. Tocava o céu. Tocava o azul. Tocava-me.

"Tu já vistes o rosto do amor?", perguntei.

Silêncio.

"Mostra-me o rosto do amor", retomei.

Ele tomou meu rosto em suas mãos, as mesmas em que carregava seu coração, levou-o para bem próximo do seu e, assim, na proximidade de um beijo, disse-me:

"Olha. Este é o único rosto que verás."

Silêncio e lágrimas. 